\title{
ДОГОВОР ДОЛЕВОГО УЧАСТИЯ В СТРОИТЕЛЬСТВЕ И ПРЕДВАРИТЕЛЬНЫЙ ДОГОВОР КУПЛИ-ПРОДАЖИ: СРАВНИТЕЛЬНЫЙ АНАЛИЗ
}

\author{
(C) 2019 Малис Жанна Вячеславовна \\ аспирант \\ Российская Государственная Академия Интеллектуальной Собственности \\ 117279, г. Москва, ул. Миклухо-Маклая, 55а \\ E-mail:2318039@bk.ru
}

В статье проводится сравнительный анализ договора долевого участия и предварительного договора купли-продажи недвижимости, в том числе, которая будет создана в будущем. Необходимость сравнительного анализа данных видов договоров вызвано тем, что в настоящий момент на практике возникает множество ситуаций, когда за договором, названным предварительным договором купли-продажи недвижимости, по факту стоит договор долевого участия в строительстве.

Критериями анализа являются такие основания как: правовое регулирование, тип порождаемых правоотношений, стороны договора, существенные условия и другие.

Ключевые слова: договор долевого участия в строительстве, предварительный договор купли-продажи недвижимости.

Сегодня активно развивается строительство жилья. При этом потребительский спрос покупки в новостройках остается достаточно высоким. Это вызвано тем, что покупка квартиры на стадии строительства обходится дешевле, чем покупка в уже введенном в эксплуатацию многоквартирном доме.

В настоящий момент покупка жилья на стадии строительства осуществляется посредством заключения договора долевого участия в строительстве, урегулированного Федеральным законом «Об участии в долевом строительстве многоквартирных домов и иных объектов недвижимости и о внесении изменений в некоторые законодательные акты Российской Федерации» от 30.12.2004 N214-Ф3 [1] (далее Федеральный закон № 214-Ф3), который предусматривает определенные гарантии участнику долевого строительства и охрану его законных интересов.

В свою очередь, часто на практике встречаются случаи, когда застройщики заключают предварительный договор купли-продажи недвижимости со стопроцентной предоплатой, тем самым пытаясь обойти нормы закона о долевом участии, при этом получив полное исполнение со стороны приобретателя и обеспечив себе капитал для строительства.

Однако само название заключаемого договора не влияет на складывающиеся между сторонами отношения. При рассмотрении дел по спорам, возникающим из правоотношений, основанных на сделках, связанных с передачей гражданами денежных средств и (или) иного имущества в целях строительства многоквартирного дома (иного объекта недвижимости) и последующей передачей жилого помещения в таком многоквартирном доме (ином объекте недвижимости) в собственность, но совершенных в нарушение требований Федерального закона «Об участии в долевом строительстве многоквартирных домов и иных объектов недвижимости», независимо от наименования заключенного сторонами договора следует исходить из существа сделки и фактически сложившихся отношений сторон [2].

Именно поэтому актуальным является вопрос об отграничении договора долевого участия в строительстве и предварительного договора купли-продажи недвижимости, определение особенности правовой природы каждого из названных договоров.

В первую очередь, для проведения сравнительного анализа, необходимо определить законодательное регулирование каждого из них, а также дать оценку порождаемых ими правоотношений.

Как уже упоминалась ранее, договор долевого участия подлежит регулированию Федеральным законом № 214-ФЗ. Согласно ч.1. ст. 4 данного закона по договору участия в долевом строительстве (далее также - договор) одна сторона (застройщик) обязуется в предусмотренный договором срок своими силами и (или) с привлечением других лиц построить (создать) 
многоквартирный дом и (или) иной объект недвижимости и после получения разрешения на ввод в эксплуатацию этих объектов передать соответствующий объект долевого строительства участнику долевого строительства, а другая сторона (участник долевого строительства) обязуется уплатить обусловленную договором цену и принять объект долевого строительства при наличии разрешения на ввод в эксплуатацию многоквартирного дома и (или) иного объекта недвижимости.

Предварительный договор купли-продажи недвижимости не имеет специализированной законодательной регламентации и регулируется общими нормами о предварительном договоре, содержащимися в Гражданском кодексе Российской Федерации [3]. Согласно п. 1 статьи 429 ГК РФ предварительный договор - это договор, по которому стороны обязуются заключить в будущем договор о передаче имущества, выполнении работ или оказания услуг.

Таким образом, характер правоотношений, порождаемых договором долевого участия в строительстве, бесспорно является имущественным, что нельзя сказать о правоотношениях, вытекающих из предварительного договора.

По мнению, Красавчикова О.А., и право, и обязанность в рассматриваемом случае не направлены непосредственно на перемещение материальных благ, не имеют имущественного содержания. Анализируемый вид правоотношений правильнее отнести к числу неимущественных (организационных) [4, с. 54]. Таким образом, в отношении предварительного договора стоит говорить скорее о его организационном характере, что подразумевает, что цель договора - не установление имущественные обязательства, а организация договорных связей между сторонами, обеспечение заключения договора в будущем.

Организационный характер данных правоотношений подтверждается и п. 6 ст. 429 ГК РФ, которая гласит, что обязательства, предусмотренные предварительным договором, прекращаются, если до окончания срока, в который стороны должны заключить основной договор, он не будет заключен либо одна из сторон не направит другой стороне предложение заключить этот договор.

Таким образом, договор долевого участия в строительстве и предварительный договор купли-продажи в первую очередь отличаются порождаемыми ими правоотношениями: при заключении договора долевого участия в строительстве между сторонами уже существуют обязательства по приему-передаче объекта, его оплате и т.д., при этом, заключая предварительный договор, между сторонами возникают лишь обязательство по заключению основного договора на данных условиях, что ещё не является свидетельством, что основное обязательство вообще возникнет (например, стороны так и не заключат основной договор купли-продажи).

Несмотря на очевидную разницу в порождаемых отношениях, очень часто на практике происходит неопределенность по поводу квалификации того или иного договора. В первую очередь, это связано с тем, что и договор долевого участия в строительстве, и предварительный договор купли-продажи может быть заключен в отношении объекта, который будет создан в будущем.

Так, согласно п. 23 Постановления Пленума Верховного Суда РФ N49 отсутствие на момент заключения предварительного или основного договора возможности передать имущество, выполнить работу, оказать услугу, являющихся предметом будущего договора, не может служить препятствием к заключению предварительного договора. Например, не требуется, чтобы товар, являющийся предметом будущего договора, имелся в наличии у продавца в момент заключения предварительного или основного договора; договор также может быть заключен в отношении товара, который будет создан или приобретен продавцом в будущем [5].

При этом стоит отметить, что договор долевого участия может быть заключен исключительно в отношении объекта, который будет создан в будущем, а точнее - до введения объекта строительства в эксплуатацию, тогда как предварительный договор купли-продажи может быть заключен и в отношении готового объекта недвижимости. Это является вторым ключевым отличием данных видом договоров.

Стоит уделить внимание и анализу форм данных договоров. Так, согласно ч.3 ст. 4 Федерального закона № 214-ФЗ договор заключается в письменной форме, подлежит государственной регистрации и считается заключенным с момента такой регистрации. В свою очередь, предварительный договор купли-продажи недвижимости согласно п. 2 ст. 429 и ст. 550 ГК РФ заключается в письменной форме путем состав- 
ления одного документа, подписанного сторонами.

Как отмечает Ибрашов Р.Т., законодательное требование о государственной регистрации договора долевого участия в строительстве исключает возможность появления нескольких претендентов на один объект недвижимости после сдачи его в эксплуатацию [6, с. 78]. Однако, что нельзя сказать о предварительном договоре, заключение которого не гарантирует, что в будущем не возникнет спорных ситуаций относительно его законного приобретателя.

Следующим существенным отличием этих договоров является момент уплаты цены договора. Согласно ч. 3 ст. 5 Федерального закона 214-ФЗ уплата цены договора производится после государственной регистрации договора путем внесения платежей единовременно или в установленный договором период в безналичном порядке. При этом сам срок уплаты должен быть указан в договоре и оплата должна быть произведена до получения недвижимости.

В свою очередь, согласно упоминаемому выше Постановлению Пленума ВС РФ если сторонами заключен договор, поименованный ими как предварительный, в соответствии с которым они обязуются, например, заключить в будущем на предусмотренных им условиях основной договор о продаже имущества, которое будет создано или приобретено в дальнейшем, но при этом предварительный договор устанавливает обязанность приобретателя имущества до заключения основного договора уплатить цену имущества или существенную ее часть, такой договор следует квалифицировать как договор купли-продажи с условием о предварительной оплате. Правила статьи 429 ГК РФ к такому договору не применяются.

Таким образом, можно сделать вывод, что невозможно заключить предварительный договор о купле-продаже будущей вещи с обязанность приобретателя имущества уплатить деньги продавцу до заключения основного договора, тогда как договор долевого участия изначально направлен на внесение денег для строительства на них объекта недвижимости.

Дальнейшему нашему анализу подлежат существенные условия исследуемых нами договоров. Относительно договора долевого участия Федеральный закон предусматривает следующий перечень его существенных условий: 1) определение подлежащего передаче конкрет- ного объекта долевого строительства; 2) срок передачи объекта долевого строительства; 3) цена договора, порядок и сроки ее уплаты; 4) гарантийный срок на объект долевого строительства; способы обеспечения исполнения застройщиком обязательств по договору. При отсутствии в договоре данных условий, он считается незаключенным.

Предварительный договор, в свою очередь, согласно п. 3 ст. 429 ГК РФ считается заключенным при наличии в нем следующих условий: 1) условие о предмете; 2) условия основного договора, относительно которых по заявлению одной из сторон должно быть достигнуто соглашение в предварительном договоре.

При этом срок не является существенным условием предварительного договора купли-продажи недвижимости. По общему правило, в случае отсутствия в предварительном договоре условий о сроке заключения основного договора, основной договор должен быть заключен в течение года с момента заключения предварительного договора.

Таким образом, договор долевого участия содержат более подробный перечень существенных условий, чем предварительный договор купли-продажи, что на наш взгляд является существенным преимуществом первого.

Заключительным критерием нашего сравнительного анализа будет являться субъектный состав данных договоров

По договору долевого участия застройщиком может быть только хозяйственное общество:1) которое имеет опыт не менее 3 лет участия в строительстве (создании) многоквартирных домов общей площадью не менее 5000 кв. метров в совокупности, при наличии полученных в порядке установленном законодательством порядке разрешений на ввод в эксплуатацию домов; 2) которое имеет в собственности или на праве аренды, на праве субаренды или в предусмотренных законом случаях - на праве безвозмездного пользования земельный участок и привлекает денежные средства участников долевого строительства для строительства (создания) на этом земельном участке; 3) наименование которого содержит слова «специализированный застройщик».

При этом в случае с предварительным договором купли-продажи недвижимости законодательно не установлено конкретных требований к создателю, таким образом, продавцом в дан- 
ном договоре может стать любое лицо, имеющее правомочие на продажу данного объекта недвижимости.

Существует различие и относительно приобретателей по данным договорам. Так согласно Федеральному закону № 214-Ф3 привлечение денежных средств граждан, связанное с возникающим у граждан правом собственности на жилые помещения в многоквартирных домах, которые на момент привлечения таких денежных средств граждан не введены в эксплуатацию в порядке, установленном законодательством о градостроительной деятельности допускается только на основании договора участия в долевом строительстве или жилищно-строительными кооперативами, которые осуществляют строительство на земельных участках, предоставленных им в безвозмездное срочное пользование в предусмотренных законом случаях.

Таким образом, невозможно заключить с гражданином предварительный договор купли-продажи не сданного в эксплуатацию жилого помещения, так как он будет квалифицироваться в любом случае как договор долевого участия в силу прямого указания на возможность привлечения денежных средств только по данному договору. На основании этого, мы можем сделать вывод, что предварительный договор купли-продажи будущей недвижимости возможно заключить только с индивидуальными предпринимателями и юридическими лицами.

Как отмечает Евстратова Н.К. инвестор, не отвечающий требованиям для застройщика, предусмотренных Ф3-214, имеет право заключать только предварительный договор купли-продажи недвижимости с юридическими лицами и не вправе привлекать денежные средства граждан для строительства [7, с. 95].

Однако, как мы отмечали выше, само название договора не будет влиять на его юридическую природу, и заключение хозяйственным обществом, не отвечающим требованиям застройщика, с гражданином договора, имеющего природу договора долевого участия в строительстве, будет лишь основанием для привлечения его к административной ответственности по 14.28 Кодекса об административных нарушения и не будет основанием для квалификации его в качестве предварительного договора купли-продажи недвижимости.

На основании проведенного анализа мы можем сделать следующие выводы:

1. Договор долевого участия в строитель- стве порождает имущественные правоотношения, тогда как предварительный договор купли-продажи недвижимости имеет своей целью возникновение лишь организационных правоотношений.

2. Договор долевого участия в строительстве может быть заключен только в отношении не введенного в эксплуатацию объекта недвижимости. В свою очередь, предварительный договор купли-продажи недвижимости возможен как в отношении будущей вещи, так и настоящей.

3. Договор долевого участия в строительстве и предварительный договор купли-продажи недвижимости заключаются в письменном виде, однако для договора долевого участия необходимо государственная регистрация, что является отдельной гарантией для приобретателя.

4. Невозможно заключить предварительный договор купли-продажи недвижимости с условием об уплате денежных средств до заключения основного договора. В свою очередь, договор долевого участия порождает обязанность уплаты цены договора до введения дома в эксплуатацию.

5. Законодательство предусматривает более широкий перечень существенных условий договора долевого участия, чем предварительного договора купли-продажи.

6. Договор долевого участия в строительстве и предварительный договор купли-продажи недвижимости отличаются по субъектному составу: законодатель предусматривает конкретные требования к застройщику по договору долевого участия, однако по предварительному договору купли-продажи недвижимости законодатель устанавливает общие правила к продавцу. Кроме того, приобретателем по предварительному договору купли-продажи будущей недвижимости могут быть только индивидуальные предприниматели и юридические лица, так как привлечение денежных средств граждан на строительство возможно только по договору долевого участия в строительстве. При этом не каждый договор, названный предварительным договор купли-продажи недвижимости и заключенный с индивидуальным предпринимателем или юридическим лицом, будет являться таковым, так как в каждом конкретном случае надо определять фактические сложившиеся между сторонами отношения и, в случае наличия признаков договора долевого участия в строительстве, квалифицировать его в качестве последнего. 


\section{Библиографический список}

1. Федеральный закон от 30 декабря 2004 г. № 214-Ф3 «Об участии в долевом строительстве многоквартирных домов и иных объектов недвижимости и о внесении изменений в некоторые законодательные акты Российской Федерации» // СЗ РФ. 2005. № 1 (часть 1). Ст. 40; СЗ РФ. 2010. № 25. Ст. 3070.

2. «Обзор практики разрешения судами споров, возникающих в связи с участием граждан в долевом строительстве многоквартирных домов и иных объектов недвижимости» (утв. Президиумом Верховного Суда РФ 04.12.2013) (ред. от 04.03.2015) // Справочно-правовая система «Консультант Плюс».

3. «Гражданский кодекс Российской Федерации (часть первая)» от 30.11.1994 N51-Ф3 (ред. от 03.08.2018) (с изм. и доп., вступ. в силу с 01.01.2019) // Справочно-правовая система «Консультант Плюс».

4. Красавчиков О.А. Гражданские организационно-правовые отношения [Текст] // Категории науки гражданского права. Избранные труды: В 2-х т. (серия «Классика российской цивилистики»). Т.I - М., 2005.

5. Постановление Пленума Верховного Суда РФ от 25.12.2018 N49 «О некоторых вопросах применения общих положений Гражданского кодекса Российской Федерации о заключении и толковании договора»// «Бюллетень Верховного Суда РФ», N2, февраль, 2019.

6. Ибрашов Р. Т. О некоторых возможных направлениях совершенствования законодательства об участии в долевом строительстве [Текст] // Юридические науки: проблемы и перспективы: материалы Междунар. науч. конф. (г. Пермь, март 2012 г.).- Пермь: Меркурий, 2012.- С. 78-81.

7. Евстратова Н.К. Практика применения договора долевого участия в строительстве и предварительного договора [Текст] // Имущественные правоотношения в Российской Федерации.- Москва, 2014. - С. $93-101$. 